\title{
Surgery makes patients happy
}

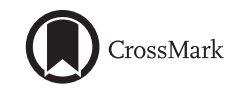

\author{
Alden H. Harken, MD, FACS \\ From the Department of Surgery, University of California, San Francisco-East Bay, Oakland, Calif. \\ Disclosures: Author has nothing to disclose with regard to commercial support. \\ Received for publication Oct 4, 2017; accepted for publication Oct 7, 2017; available ahead of print Nov 2, 2017. \\ Address for reprints: Alden H. Harken, MD, FACS, Department of Surgery, University of California, San \\ Francisco-East Bay, 1411 E 31st St (QIC 22134), Oakland, CA 94602 (E-mail: alden.harken@ucsfmedctr.org). \\ J Thorac Cardiovasc Surg 2018;155:970-1 \\ $0022-5223 / \$ 36.00$ \\ Copyright (c) 2017 by The American Association for Thoracic Surgery \\ https://doi.org/10.1016/j.jtcvs.2017.10.020
}

As recently as 2 decades ago, most of us believed that the substrate for atrial fibrillation (AF) was thousands of stretched (and therefore ischemic) atrial cardiomyocytes firing randomly and completely independently. We also assumed that this essentially continuous electrical chaos left most of the atria refractory most of the time. The conceptual breakthrough occurred when $\operatorname{Jim} \operatorname{Cox}^{1}$ postulated the intuitively impossible (at least to me) idea that a pathway-seeking electrical impulse could continuously discover circuitous pathways of excitable (nonrefractory) atrial myocytes and successfully negotiate them to sustain a reentrant rhythm. Thus, AF is a reentrant rhythm.

For reentry to be sustained it obligates (1) slow conduction, (2) rapid refractoriness, and (3) unidirectional block, and it is facilitated by micro-anatomic heterogeneity. An impulse must take long enough traveling over a circuitous path for the origin to have had time to repolarize upon its return. Now, Jimmy reasoned that the larger the mass of myocardium, the more likely a wayward impulse would be able to find a sufficiently distant and time-consuming trajectory for the origin to regain excitability. So he suggested that we cut the atria up into strips, and any wayward impulse would be forced to stay local and arrive home too fast for reentry to be sustained. The good news is that Jimmy was right. The bad news was that with the early Cox-Maze procedures, after atrial slicing, the operative field looked like a lawnmower accident. So, surgeons and cardiologists began cutting corners with fewer incisions. The procedures were technically easier, but, the results were not as good. ${ }^{2}$

So, why not add ganglion plexus ablation to a limited Cox-Maze? Perhaps this would boost the results of this easier procedure. This strategy enjoyed conceptually intuitive promise. Efferent sympathetic preganglionic neurons that control cardiac function exit via the ventral rami of segments T1-T4 to the sympathetic chain and synapse on axons within the stellate ganglion at spinal levels T2-T4. ${ }^{3}$ Sympathetic denervation of the heart has been appended to therapies for many disparate diseases ranging from myocardial ischemia to thyrotoxicosis.

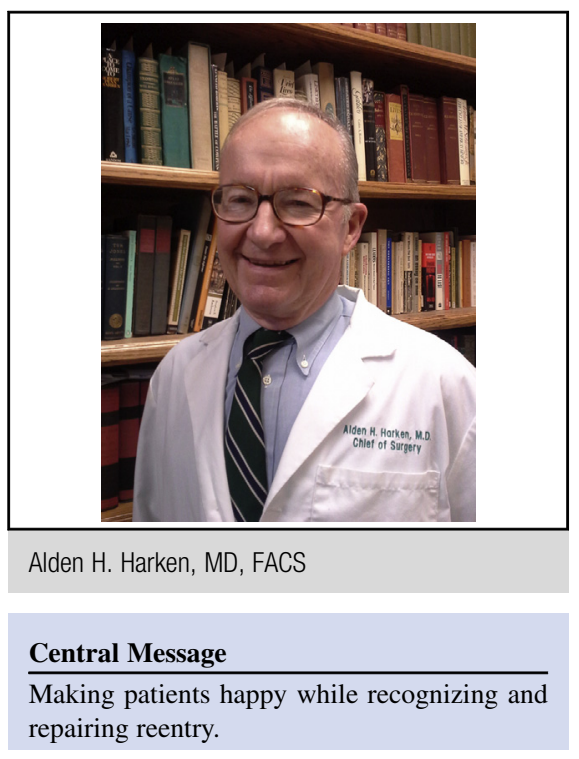

See Article page 972.

The accompanying important article ${ }^{4}$ is based on the Atrial Fibrillation Ablation and Autonomic Modulation via Thoracoscopic Surgery study, ${ }^{5}$ in which 240 patients underwent a thoracoscopic pulmonary vein isolation (a mini Cox-Maze procedure) and were preoperatively randomized to an additional ganglion plexus ablation or no additional therapy.

Unfortunately, the additional sympathetic neurectomy did not seem to help. ${ }^{5}$ For those of us in search of less-challenging surgical or interventional cardiologic procedures, the news is also bad: The old-fashioned cut-and-sew Cox-Maze III continues to offer significantly greater freedom from atrial fibrillation off medications than any other combination of lesion sets. ${ }^{2}$

Interestingly, the accompanying study ${ }^{4}$ does conclude that patients feel better (by Short Form-36) after thoracoscopic pulmonary vein isolation even if they have experienced a single recurrence. Not surprisingly, however, when patients experience multiple recurrences-especially if they experience complications-they are not happy. Most of us know this firsthand.

\section{References}

1. Cox J, Schuessler R, D'Agostino H, Stone C, Chang B, Cain M, et al. The surgical treatment of atrial fibrillation. III. Development of a definitive surgical procedure. J Thorac Cardiovasc Surg. 1991;101:569-83.

2. Stulak JM, Suri RM, Burkhart HM, Daly RC, Dearani JA, Greason KL, et al. Surgical ablation for atrial fibrillation for two decades: are the results of new techniques equivalent to the Cox-Maze III procedure? J Thorac Cardiovasc Surg. 2014;147:1478-86. 
3. Ajijola OA, Vaseghi M, Mahajan A, Shivkumar K. Bilateral cardiac sympathetic denervation: why, who, and when? Expert Rev Cardiovasc Ther. 2012;10:947-9.

4. Driessen AHG, Berger WR, Bierhuizen MFA, Piersma FR, van den Berg NWE, Neefs J, et al. Quality of life improves after thoracoscopic surgical ablation of advanced atrial fibrillation: Results of the Atrial Fibrillation Ablation and
Autonomic Modulation via Thoracoscopic Surgery (AFACT) study. J Thorac Cardiovasc Surg. 2018;155:972-80.

5. Driessen AHG, Berger WR, Krul SPJ, van den Berg NWE, Neefs J, Piersma FR, et al. Ganglion plexus ablation in advanced atrial fibrillation: the AFACT study. J Am Coll Cardiol. 2016;68:1155-65.

Access to The Journal of Thoracic and Cardiovascular Surgery Online is reserved for print subscribers!

Full-text access to The Journal of Thoracic and Cardiovascular Surgery Online is available for all print subscribers. To activate your individual online subscription, please visit The Journal of Thoracic and Cardiovascular Surgery Online, point your browser to http://www.mosby.com/itcvs, follow the prompts to activate your online access, and follow the instructions. To activate your account, you will need your subscriber account number, which you can find on your mailing label (note: the number of digits in your subscriber account number varies from 6 to 10 ). See the example below in which the subscriber account number has been circled:

\section{Sample mailing label}

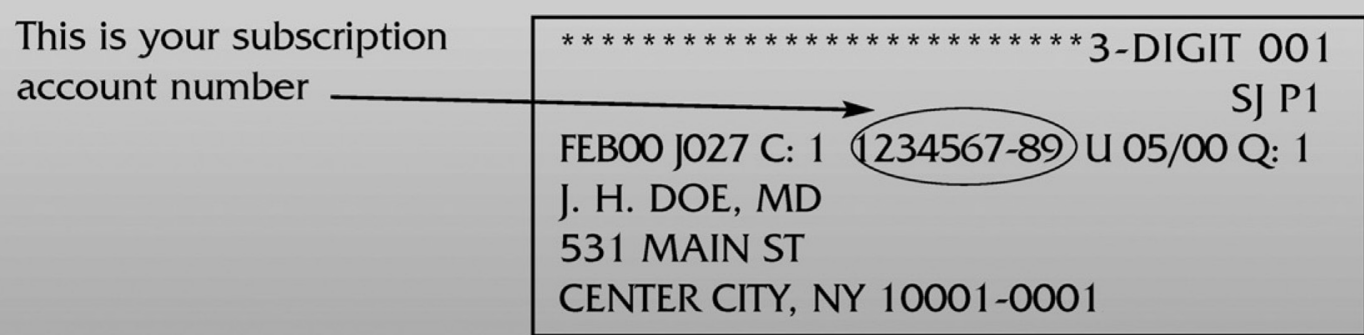

Personal subscriptions to The Journal of Thoracic and Cardiovascular Surgery Online are for individual use only and may not be transferred. Use of The Journal of Thoracic and Cardiovascular Surgery Online is subject to agreement to the terms and conditions as indicated online. 